\title{
Phosphomonoesterase activity under different microbiological soil properties
}

\begin{abstract}
In the present work, effects of microbiological soil properties and phosphomonoesterase activity are presented. The abundances of ammonificators, fungi, actinomycetes, Azotobacter sp., cellulolytic microorganisms, microorganisms that solubilize organic and inorganic $P$ compounds bound to $\mathrm{Al}, \mathrm{Fe}$ and $\mathrm{Ca}$, have been determined by the dilution method with application of selective nutrient mediums. The first five axes explaines $86 \%$ of the total variance. The first axis explains $34.6 \%$ of variance and it appears to reflect the processes of microbiological mineralization and immobilization of phosphorus. The second axis explains $25.9 \%$ of variance and reflects microbial activity and organic matter accumulation, $N$ biomasses, Azotobacter sp. abundance and acid and alkaline PME activities. Phosphomonoesterase activity in soil depend primarily on soil organic matter and biological factors and can be used as a parameter of plants' uptake of phosphorus, especially in conditions of its low concentration in soil.
\end{abstract}

Keywords: microorganisms, soil, microbial biomass

\section{INTRODUCTION}

The transformations of organic and inorganic forms of $P$ are closely interrelated and included in the soil $P$ cycle. The availability of phosphorus is often controlled by activity of microorganisms, primarily their enzymes, which play the key role in biological activity of soil [1] and provide a biological assessment of soil [2]. Concept of soil quality includes different biological and microbiological parameters such as soil enzymes [3]. Enzymes synthesis is soil is continual; they have a great importance for agricultural production [4]. Different microbial populations might have developed with different turnover rates and $\mathrm{P}$ cycling rates through their biomasses [5]. Biological and biochemical control of $\mathrm{P}$ cycle in soil depend on organic phosphates mineralization, i.e. on acid phosphatase activity and on the content of inorganic phosphates. Enzymes play a key role in biochemical cycling of nutrients in soils [6]. Activity of soil enzymes is in correlation with properties of soil [7], vegetation [8], succession [9] microbial population [10].

One of most examinated enzymes are phosphomonoesterases, who catalyze hydrolysis of orthophosphorous acid esters and are involved in processes of mineralization of organic $\mathrm{P}$ compounds [11]. These enzymes have an important

Author's address: ${ }^{1}$ Faculty of Agriculture, University of Belgrade, Nemanjina 6, Zemun-Belgrade, Serbia, ${ }^{2}$ Biounik d.o.o. Research and Development Center, Šimanovci, Serbia, ${ }^{3}$ Department of Ecology and Animal feed, Institute for Animal Husbandry, Belgrade-Zemun

Received for Publication: 10. 01. 2014.

Accepted for Publication: 14. 04. 2014. role in supplying of plants with available phosphorus. Soil phosphomonoesterases originate from plant roots and microorganisms [12]. The synthesis of these enzymes is in correlation with soil enzymatic activity [13]. The present work includes researches of abundance of various microorganism groups, microbiological biomass content in different soil types and phosphomonoesterase activities.

\section{MATERIALS AND METHODES}

The investigated soils belong to different types, subtypes, modes of utilization and sampling sites in Serbia (Table 1). Ten pedological profiles were opened per each type and subtype of soil, selecting representative ones, from which samples were collected along genetical horizons down to original substrate, except in the case of chernozem in Zemun Polje.

Acid and alkaline phosphomonoesterase (PME) activities were determined utilizing a modified universal buffers $\mathrm{pH} 6.5$ and 11 according to Tabatabai [14]. Measurement of phosphomonoesterase activity was conducted in four replications and expressed in pmol p-nitrophenole $\mathrm{g}^{-1} \mathrm{~s}^{-1}$

Microbial biomass of $C$ has been determined by fumigation-incubation method [15]. Microbial biomass was calculated as $\mathrm{Fc} / \mathrm{kc}$ (15) where $\mathrm{Fc}$ is $\left(\mathrm{CO}_{2}-\mathrm{C}\right.$ evolved from fumigated soil during $0-10 \mathrm{~d}$ incubation) - $\left(\mathrm{CO}_{2}-\mathrm{C}\right.$ evolved from nonfumigated soil during $0-10 \mathrm{~d}$ incubation) and $\mathrm{kc}$ is 0.45 [16]. $\mathrm{N}$ biomass has been determined by incubation of fumigated and non-fumigated soil samples at 25 ${ }^{\circ} \mathrm{C}$, at $60 \% \mathrm{WHC}$, for 14 days [17]. Extraction was performed with $2 \mathrm{M} \mathrm{KCl}$, and $\mathrm{NO}_{3}{ }^{-}-\mathrm{N}$ and $\mathrm{NH}^{+}-\mathrm{N}$ in the extract were determined [18]. $\mathrm{N}$ biomass has been calculated on the basis of differences between net amount of min- $\mathrm{N}$ produced in fumigated, 
non-fumigated soils and before incubation, using risk factor $k=0.33$. $P$ biomass has been determined according to Brookes [19]. The initial incubation of the samples under moist conditions in the presence of soda lime for 10 days was followed by fumigation [15]. Microbiological $\mathrm{P}$ was determined according to Murphy and Riley [20]. Correction for the adsorbed $P$ during extraction was performed according to Brookes [19].

Table 1 - Types of the sampled soils

\begin{tabular}{|c|c|c|c|c|c|}
\hline $\begin{array}{l}\text { No. } \\
\text { prof }\end{array}$ & $\begin{array}{c}\text { Soil type } \\
\text { (soil subtype) }\end{array}$ & $\begin{array}{c}\text { Depth } \\
(\mathrm{cm})\end{array}$ & Site & $\begin{array}{l}\text { Vegetation } \\
\text { type }\end{array}$ & $\begin{array}{c}\text { Texture } \\
\text { class }\end{array}$ \\
\hline 1 & $\begin{array}{l}\text { Calcomelanosol } \\
\text { (Organo-mineral black } \\
\text { soil) }\end{array}$ & $0-20$ & Rajac & Pasture & Silty clay \\
\hline 2 & $\begin{array}{l}\text { Calcomelanosol } \\
\text { (Brownized calcareous } \\
\text { black soil) }\end{array}$ & $\begin{array}{c}0-20 \\
20-40 \\
40-60\end{array}$ & Rajac & Pasture & $\begin{array}{l}\text { Heavy } \\
\text { clay }\end{array}$ \\
\hline 3 & $\begin{array}{l}\text { Calcomelanosol } \\
\text { (Lessive calcareous } \\
\text { black soil) }\end{array}$ & $\begin{array}{l}0-15 \\
30-50 \\
50-70\end{array}$ & Rajac & Pasture & Silty clay \\
\hline 4 & Solonetz & $\begin{array}{l}0-15 \\
30-50 \\
50-70\end{array}$ & Kumane & Uncultivated land & Silty clay \\
\hline 5 & Chernozem & $\begin{array}{c}0-20 \\
20-40\end{array}$ & Zemun Polje & Maize & Silty clay \\
\hline 6 & Chernozem & $\begin{array}{l}0-20 \\
20-40\end{array}$ & Roman ditches & Soybean & Light clay \\
\hline 7 & Humogley & $\begin{array}{l}0-30 \\
30-70 \\
\end{array}$ & Becej & Winter wheat & $\begin{array}{l}\text { Heavy } \\
\text { clay }\end{array}$ \\
\hline 8 & Fluvisol & $\begin{array}{l}0-30 \\
30-70\end{array}$ & $\begin{array}{l}\text { Kaska } \\
\text { forest }\end{array}$ & $\begin{array}{c}\text { Poplar } \\
\text { plantation }\end{array}$ & Sand \\
\hline
\end{tabular}

Microbiological analyses included determination of ammonificators, fungi, actynomycetes, Azotobacter sp. and cellulolytic microorganisms. The abundance of microorganisms solubilizing inorganic P compounds (PSM) was determined on glucose- asparagine substrate according to Muramtsov $\left(10^{-4}\right)$ with the following composition: asparagine $1 \mathrm{~g}$, glucose $10 \mathrm{~g}, \mathrm{~K}_{2} \mathrm{SO}_{4} 0.2 \mathrm{~g}, \mathrm{MgSO}_{4}$ $0.2 \mathrm{~g}$, maize extract $0.02 \%$, agar $20 \mathrm{~g}$, and tap water $1000 \mathrm{ml}$. The substrate was supplied also with $1.5 \mathrm{~g} \mathrm{CaCO}_{3}\left(\mathrm{PO}_{4}\right)_{2}, 0.264 \mathrm{~g} \mathrm{AlPO}_{4}$ and $0.28 \mathrm{~g}$
$\mathrm{FePO}_{4}$, for determination of PSM-Ca, $\mathrm{Al}$ and Fe. Abundance of microorganisms transforming organic phosphates (PSM-Po) was determined on Menkine substrate [21] with lecithine as a sole $P$ source. As a mathematical model for the interrelation of the investigated parameters, correlation coefficient was calculated, expressing the strength of relationship between the investigated components. Starting from indicators defined in this way, we have examined the nature of factor spaces for microbiological properties of soils. 


\section{RESULTS}

The abundance of ammonificators, actynomycetes, Azotobacter sp., PSM-Po and PSM-Ca, $\mathrm{Al}$ and $\mathrm{Fe}$ is higher in chernozem and humogley compared to the remaining investigated soil types, while the abundance of fungi is highest in calcomelanosol. Microorganisms solubilizing $\mathrm{FePO}_{4}$ are represented more poorly than those solubilizing $\mathrm{AlPO}_{4}$, but more abundantly than PSM-Ca. (Table 2).

Table 2 - Microbiological soil properties

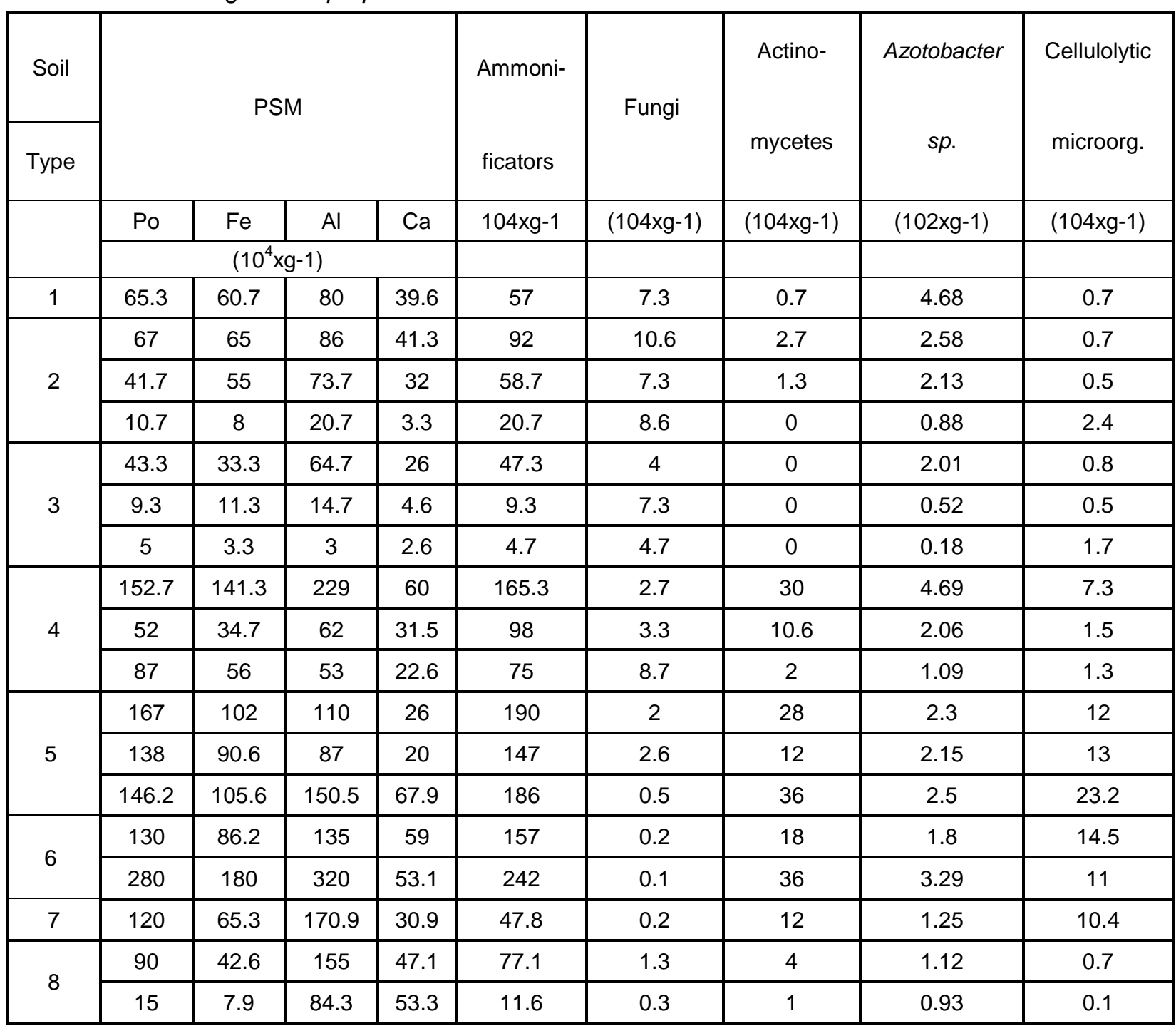

Activities of acid and alkaline PME are significantly correlated with $\mathrm{C}$ and $\mathrm{N}$ biomasses, but not with $\mathrm{P}$ biomass (Table 3 ).

Alkaline PME activity correlates positively with the abundances of all microorganism groups, while the acid PME is significantly correlated only with the abundance of Azotobacter sp. and fungi.

Principal components analysis was used to investigate relationships among biochemical and microbiological properties (Table 4). The first five axes explained $86.04 \%$ of the total variance. The first axis explained $34.6 \%$ of variance and appears to reflect microbiological activity: abundance of cellulolytic microorganisms, PSM-Po and PSM-Fe and PSM-AI, aminoheterotrophs, actinomycetes, $\mathrm{P}$ biomass and available $P$ content in soil. The second axis explaines $25.9 \%$ of variance and reflects microbial activity and organic matter accumulation: positive correlation with humus and total $\mathrm{N}$ contents, biomasses of $\mathrm{C}$ and $\mathrm{N}$, Azotobacter abundance and acid and alkaline PME activities; and a negative with $\mathrm{pH}$. 
Table 3 - Correlation coefficients between PME activity, microbiological biomass and microorganism's abundance

\begin{tabular}{|l|c|c|c|c|c|}
\hline & Acid & Alkaline & \multirow{2}{*}{ Biomass C } & Biomass & \multirow{2}{*}{ Biomass P } \\
\cline { 2 - 3 } & PME & PME & & $\mathrm{N}$ & \multirow{2}{*}{-0.1} \\
\hline Acid PME & 1 & $0.77 \mathrm{a}$ & $0.62 \mathrm{a}$ & $0.71 \mathrm{a}$ & 0.28 \\
\hline Alkaline PME & $0.77 \mathrm{a}$ & 1 & $0.79 \mathrm{a}$ & $0.72 \mathrm{a}$ & 0.44 \\
\hline Biomass C & $0.62 \mathrm{a}$ & $0.79 \mathrm{a}$ & 1 & $0.63 \mathrm{a}$ & 0.16 \\
\hline Biomass N & $0.71 \mathrm{a}$ & $0.72 \mathrm{a}$ & $0.63 \mathrm{a}$ & 1 & 1 \\
\hline Biomass P & -0.1 & 0.28 & 0.44 & -0.16 & $0.86 \mathrm{a}$ \\
\hline PSM - Po & -0.06 & 0.38 & $0.49 \mathrm{~b}$ & 0.01 & $0.77 \mathrm{a}$ \\
\hline PSM - Fe & 0.03 & 0.39 & $0.61 \mathrm{a}$ & 0.26 & $0.66 \mathrm{a}$ \\
\hline PSM - Al & 0.1 & $0.57 \mathrm{a}$ & $0.57 \mathrm{a}$ & 0.08 & 0.39 \\
\hline PSM - Ca & 0.16 & 0.45 & 0.45 & 0.19 & $0.82 \mathrm{a}$ \\
\hline Ammonifiers & -0.05 & 0.46 & $0.47 \mathrm{~b}$ & 0.13 & $-0.58 \mathrm{~b}$ \\
\hline Fungi & $0.49 \mathrm{~b}$ & 0.18 & -0.14 & 0.37 & $0.82 \mathrm{a}$ \\
\hline Actynomycetes & -0.21 & 0.32 & 0.44 & 0.04 & 0.3 \\
\hline Azotobacter sp. & $0.53 \mathrm{a}$ & $0.80 \mathrm{a}$ & $0.73 \mathrm{a}$ & $0.72 \mathrm{a}$ & $0.82 \mathrm{a}$ \\
\hline Cellulolitic mic. & -0.3 & 0.17 & 0.34 & -0.21 & \\
\hline
\end{tabular}

$\mathrm{a}-\mathrm{P}<0.01$

$\mathrm{b}-\mathrm{P}<0.05$

Table 4 - Rotated factor matrix for soil microbiological properties

\begin{tabular}{|l|c|c|c|c|c|}
\hline & Factor 1 & Factor 2 & Factor 3 & Factor 4 & Factor 5 \\
\hline PSM - Po & $0.918 \mathrm{a}$ & 0.059 & 0.033 & 0.166 & 0.202 \\
\hline PSM - Fe & $0.877 \mathrm{a}$ & 0.264 & 0.031 & 0.113 & 0.268 \\
\hline PSM - Al & $0.791 \mathrm{a}$ & 0.209 & 0.32 & 0.345 & -0.01 \\
\hline PSM - Ca & 0.545 & 0.283 & 0.676 & 0.037 & 0.017 \\
\hline Ammonifiers & $0.902 \mathrm{a}$ & 0.078 & 0.041 & -0.001 & 0.307 \\
\hline Fungi & -0.64 & 0.324 & -0.45 & 0.017 & 0.325 \\
\hline Actinomycetes & $0.932 \mathrm{a}$ & -0.01 & 0.074 & -0.05 & 0.066 \\
\hline Azotobacter sp. & 0.446 & $0.700 \mathrm{a}$ & 0.163 & -0.07 & 0.342 \\
\hline Cellul. mic. & $0.854 \mathrm{a}$ & -0.18 & -0.06 & -0.32 & -0.14 \\
\hline Biomass C & 0.495 & $0.777 \mathrm{a}$ & 0.011 & -0.13 & -0.16 \\
\hline Biomass N & -0.05 & $0.834 \mathrm{a}$ & 0.011 & -0.24 & 0.265 \\
\hline Biomass P & $0.910 \mathrm{a}$ & -0.04 & -0.19 & 0.022 & -0.08 \\
\hline Expl.Var & 7.789 & 5.589 & 3.974 & 1.576 & 1.722 \\
\hline Prp.Totl & 0.325 & 0.233 & 0.166 & 0.066 & 0.072 \\
\hline
\end{tabular}

a - Marked loadings are $>0.700$ 


\section{DISCUSSION}

Soil function mainly involves recycling of organic inputs and maintenance of physical structure. These processes are regulated by a suite of hierarchically organized factors [22] operated at nested scales of space and time in other: climate, soil (clay and nutrient status) properties, organic matter, macro- and microorganisms. PME activity, microorganism abundance and microbiological biomass have been determined in soils formed under the influence of various pedogenetic factors and which differ from one another by chemical and physical properties [13]. Alkaline PME is an enzyme of microbiological origin and depends on the number of microorganisms that synthesize it [23]. However, acid PME is produced by microorganisms and plant roots and thus it is not directly dependent on the abundance of microorganisms. Nakas [24] state that bacterial isolates have 10-100 times higher phosphatase activities than fungi isolates. The same authors state that the activity of alkaline phosphatase increases when amino acid is introduced in soil. High microbiological activity and PME exudation may decrease phosphatase activity. Few previous studies have addressed the decrease of PME activity [25] with soil depth. This conclusion is in correspondence with our results.

Dominant group of microorganism are ammonificators, actinomycetes, Azotobacter sp. and PSM, especially in chernozem and humogley. Some reports [26, 27] confirmed also the highest abundance of same microbial groups in chernozem and humogley. The results of this investigation show that PME activity was not significantly correlated with biomass of phosphorus. However, Sparling [28] find significant correlation coefficients. Biological mechanisms play an important role in controlling the magnitude and forms of phosphorus release from the soil although they have been underrepresented in the past. Ammonificators and PSM-Po mineralize organic nitrogen and phosphorus compounds bound to PSM-Al and $\mathrm{Fe}$ phosphates. In the association of phosphorus components with organic matter there are Al-phosphates and Fe-phosphates (but not $\mathrm{Ca}$ - phosphates). Rojo [29] showed a significant correlation between the contents of organic phosphorus, Alphosphates, Fe-phosphates and phosphatase activities. Through decomposition processes, $\mathrm{P}$ of biological origin supplies nearly $87 \%$ and weathering of primary inorganic $P$ furnishes $13 \%$ of the total $P$ taken up by plants [30]. Phosphorus held in the soil microbial biomass $\left(P_{\text {mic }}\right)$ is the most rapidly cycling organic $P$ pool and may play an important role in plant nutrition, especially in natural eco- and low input agrosystems.

\section{CONCLUSION}

Activities of acid and alkaline PME are significantly correlated with $\mathrm{C}$ and $\mathrm{N}$ biomasses, but not with $\mathrm{P}$ biomass. Alkaline PME activity correlates positively with the abundances of all microorganism groups, while the acid PME is significantly correlated only with the abundance of Azotobacter sp. and fungi.

This research may be helpful for studying of phosphatase activity in different soil types and can be used as a parameter of plants uptake of phosphorus, especially in conditions of its low concentration in soil.

\section{REFERENCES}

[1] Balota E.L., Kanashiro M., Filho A.C., Andrade D.S., Dick R.P., (2004) Soil enzyme activities under longterm tillage and crop rotation systems. Braz. J. Microbiol., 35, p.300-306.

[2] Bandick A.K., Dick R.P, (1999) Field management effects on soil enzyme activities. Soil Biol. Biochem. 31, p.1471-1479.

[3] Valarini P.J., Alvarez M.C.D., Gasco J.M., Guerrero F., Tokeshi H., (2002) Integrated evaluation of soil quality after the incorporation of organic matter and microorganisms. Braz. J. Microbiol., 33, p. 35-40.

[4] Dick R.P., (1997) Soil enzyme activities as integrative indicators of soil health. In: Pankhurst, C.E.; Doube, B.M.; Gupta, V.V.S.R. (eds.) Biological Indicators of Soil Health. CAB International, p.121156.

[5] Oehl F., Oberson A., Frossard E., Fließbach A., Probst M., (1998) Phosphorus in soil microbial biomass - influence of conventional and biological farming, ed. ISSS, World Congress of Soil Science, Montpellier.

[6] Caldwell B.A., (2005) Enzyme activities as a component of soil biodiversity: a review. Pedobiologia, 49, p.637-644.

[7] Chodak M and Niklinska M., (2012). Development of Microbial Biomass and Enzyme Activities in Mine Soils. Polish Journal of Environmental Studies, 21(3) 569-577.

[8] Sinsabaugh R.L., Carreiro M.M., Repert D.A., (2002) Allocation of extracellular enzymatic activity in relation to litter composition, $\mathrm{N}$ deposition, and mass loss. Biogeochemistry, 60, p.1-24.

[9] Tscherko D., Rustemeier J., Richter A., Wanek W., Kandeler E., (2003) Functional diversity of the soil microflora in the primary successon across two glacier forelands in the Central Alps. Eur. J. Soil Sci., 54, p.685-696.

[10] Kourtev P.S., Ehrenfeld J.G., Haggblom M., (2002) Exotic plant species alter the microbial community structure and function in the soil. Ecology, 83, p. 3152-3166.

[11] Bunemann E.K., Bartlomiej P., Ehlers K., (2011) Phosphorus in Action: Biological Processes in Soil Phosphorus Cycling. Springer-Verlag Berlin Heidelberg, p. 498. 
[12] Rejsek K., Vranova V., Formanek P., (2012) Determination of the Proportion of Total Soil Extracellular Acid Phosphomonoesterase (E.C. 3.1.3.2) Activity Represented by Roots in the Soil of Different Forest Ecosystems. The Scientific World Journal http://dx.doi.org/10.1100/2012/250805.

[13] Djordjevic S., (1998) Phosphomonoesterase activity in soil under corn. Novi Sad, Serbia, Doctoral thesis, $\mathrm{p}: 192$.

[14] [14] Tabatabai, M.A., (1982) Soil enzymes. In A. L. Page et al.(Eds.) Methods of soil analysis, Part 2. Chemical and microbiological properties, 2nd edn, American Society of Agronomy, Madison, WI, 1982 , p. 903-947.

[15] Jenkinson D.S., Powlson D.S., (1976) The effects of biocidal treatments on metabolism in soil. V. A method for measuring soil biomass. Soil Biol. Biochem., 8, p. 209-213.

[16] Jenkinson D.S., (1988) Determination of microbial biomass carbon and nitrogen in soil. In: Wilson, J. R. (Ed.), Advances in nitrogen cycling and agricultural ecosystems. CAB International, Wallingford, p.368 386.

[17] Ross D.J., Tate K.R., Cains A., Meyrick K.F., (1980) Influence of storage on soil microbial biomass estimated by three biochemical procedures. Soil Biol. Biochem.,12, p.369-374.

[18] Bremner J.M., (1965) Organic forms of nitrogen.. In C.A. Black et al. (ed.) Methods of soil analysis. Agron. Monogr. 9. Part 2., ASA, Madison, WI, p: 1238-1255.

[19] Brookes P.C., Powlson D.S., Jenkinson D.S., (1982) Measurement of microbial biomass phosphorus in soil. Soil Biol. Biochem., 14, p.319-329.

[20] Murphy J., Riley J.P., (1962) A modified single solution method for the determination of phosphate in natural waters. Anal. Chim. Acta, 27, p.31-36.

[21] Rodina A.C.,(1965) Methods in Aquatic Microbiology
(Revised translation 1972). Colwell, R. K. and Zambruski. M. S. Baltimore (eds). University Park Press.

[22] Beare M.H., Coleman D.C., Crossley D.A., Hendrix P.F., Odum E.P., (1995) A hierarchical approach to evaluating the significance of soil biodiversity to biogeochemical cycling. Pl. Soil, 31, p.1-18.

[23] Huang M.P., Li Y., Sumner M., (2012) Handbook of soil sciences properties and processes. Second edition. CRC Press.Taylorand Francis Group. Boca Raton, FL, United States of America, p.26-43.

[24] Nakas J.P., Gould W.D., Klein D.A.,(1987) Origin and expression of phosphatase activity in semi - arid grassland soil. Soil Biol. Biochem., 19, p.13-18.

[25] Khaziev F.K.H., Burangulova M.N., (1965) Activity of enzymes which dephosphorylate organic phosphorus compounds of soil. Prikl. Biokhim. Mikrobiol.,1, p.373-379.

[26] Marinkovic J., Milosevic N., Tintor B., Sekulic P., Nesic Lj., (2008) Microbial properties of fluvisol at different locations in the vicinity of Novi Sad, Proc. Sci. Inst. Crop. Sci., 45, p.215-223.

[27] Tintor B., Milosevic N., Sekulic P., Marinkovic J., Cvijanovic G., (2007) Microbiological properties of chernozem at several locations near Novi Sad. Proc. Sci. Inst. Crop. Sci., 43, p.311-318.

[28] Sparling G.R., Speir T.W., Whale K.N., (1986) Changes in Microbial biomass C, ATP contet, soil phospho - monoesterase and phospho-diesterase activity following air-drying of soils. Soil Biol. Biochem., 18, p.363-370.

[29] Rojo M.J., Carcedo S.G., Mateos M.P., (1990) Distribution and characterization of phosphatase and organic phosphorus in soil fractions. Soil Biol. Biochem., 22, p.169-174.

[30] Wood T.E., Bormann F.H., Voigt G.K., (1984) Phosphorus cycling in a northern hardwood: Biological and chemical control. Science (Washington, DC), 223, p.391- 393.

\section{IZVOD}

\section{AKTIVNOST FOSFOMONOESTERAZE U ZAVISNOSTI OD MIKROBIOLOŠKIH SVOJSTAVA ZEMLJIŠTA}

$U$ ovom radu ispitivan je uticaj mikrobioloskih svojstava zemljista i aktivnosti fosfomonoestreaze. Brojnost azotofiksatora, gljiva, aktinomiceta, Azotobacter sp., celulolitičkih mikroorganizama, mikroorganizma koji razlazu organske i neorganske jedinjenja vezana za $P, A l, F e ~ i ~ C a$, utvrđene su postupkom razređivanja s primenom selektivnih hranjivih medija. Prvih pet osa objasnjava $86 \%$ ukupne varijanse. Prva osa objašnjava $34,6 \%$ varijanse, a odražava procese mikrobiološke mineralizacije $i$ imobilizacije fosfora. Druga osa objašnjava $25,9 \%$ varijanse $i$ odražava mikrobiološku aktivnost $i$ nakupljanje organske materije, $N$ biomase, brojnost Azotobacter sp. $i$ aktivnosti kisele $i$ alkalne fosfomonoesteraze.

Fosfomonoesterazna djelovanja u tlu primarno zavise od organske materije i bioloških faktora i može se koristiti kao parametar biljnog usvajanja fosfora, naročito u uslovima njegove niske koncentracije u tlu.

Ključne reči: mikroorganizmi, zemljište, mikrobiološka biomasa

Originalni naučni rad

Primljeno za publikovanje: 10. 01. 2014.

Primljeno za publikovanje: 14. 04. 2014. 